\title{
The relationship between diet and other elements of lifestyle and the health status of adult high school students
}

\author{
MAŁGORZATA KOZIARSKA-ROŚCISZEWSKA ${ }^{1, \text { A-E, }}$, KATARZYNA WIŚNIEWSKA ${ }^{2, \text { A-F }}$ \\ ${ }^{1}$ Department of Nephrology, Hypertension and Family Medicine, Medical University of Lodz, Poland \\ ${ }^{2}$ Students' Scientific Association of Family Medicine, Medical University of Lodz, Poland
}

A - Study Design, B - Data Collection, C - Statistical Analysis, D - Data Interpretation, E - Manuscript Preparation, F - Literature Search, G - Funds Collection

Summary Background. Obesity is one of the main causes of "civilization-related" diseases (diabetes mellitus, hypertension, atherosclerosis). Poor dietary habits can influence health even in teenagers.

Objectives. The aim of the study was to analyze the relationship between the lifestyle and health of adult high school students (18-20 years old) from Lodz.

Material and methods. A group of 106 high school students in Lodz (76 women - 71.7\% and 30 men - 28.3\%) were enrolled. A questionnaire concerning lifestyle and selected diseases was completed. Anthropometric measurements and physical examination were carried out. BMI and WHR were calculated. In addition, in 35 volunteers out of the respondents blood tests (lipids, glycemia) were done.

Results. BMI was $\geq 25 \mathrm{~kg} / \mathrm{m}^{2}$ among 19 students (18\%). Abnormal waist circumference was observed in 8 (8\%) patients, 1 person had abnormal WHR (0.9\%). Elevated systolic and/or diastolic blood pressure was observed in 4 students (4\%). Elevated total cholesterol was found in 4 respondents (4\%), hyperglycemia in the case of 1 person (0.9\%). 73 participants $(68.9 \%)$ attended physical education classes; $62(58.5 \%)$ of them were physically active in their leisure-time.

Conclusions. In the examined group of adult high school students cardiovascular risk factors (excessive body weight, dyslipidemia, hypertension) were observed. Improper dietary habits affect the health status in teenagers. The physical activity of the examined young people seems satisfactory. Most of the high school students participate in physical training at school and spend their leisure-time actively. Preventive methods in young people should include proper diet and the promotion of an active lifestyle.

Key words: obesity, dietary habits, lifestyle, overweight, youth, Young Adult.

Koziarska-Rościszewska M, Wiśniewska K. The relationship between diet and other elements of lifestyle and the health status of adult high school students. Fam Med Prim Care Rev 2017; 19(3): 230-234, doi: https://doi.org/10.5114/fmpcr.2017.69281.

\section{Background}

With the development of civilization, an increasing incidence of metabolic diseases is observed. One of the main causes of this is obesity. Obesity contributes to multiple health pathologies. Fat accumulation has an influence on many conditions leading to the development of atherosclerosis and its serious consequences (e.g. heart attack, stroke). Pathological changes occur in all systems and organs. Lipid abnormalities are more common in obese people. Obesity increases the risk of coronary heart disease leading to, e.g. circulatory insufficiency, as well as to increased death risk $[1,2]$. Obesity and diabetes can also coexist with autoimmune diseases, especially Hashimoto's thyroiditis [3]. Metabolic changes that result from excessive body mass can cause damage to the central nervous system (CNS). Overweight and obesity contribute to the development of Alzheimer's disease and Parkinson's disease. Obese people often suffer from diabetes mellitus type 2 . Diabetes, in turn, is closely linked to the development of neurodegenerative diseases. The relationship between overweight and insulin resistance (which plays a major role in the development of dementia) may also be a cause of changes in the CNS [4].

Metabolic syndrome, the main criterion for the diagnosis of which is central obesity, is also a risk factor for the development of chronic kidney disease. Overweight and obesity among children and adolescents are conducive to the occurrence of metabolic syndrome, even four times more often than among children with normal weight. The sooner the patient develops metabolic syndrome, the greater the risk of complications of chronic kidney disease in the future [5].

According to world data, the occurrence of overweight and obesity affects all age groups - adults, children and adolescents. About 107.7 million children and 603.7 adults worldwide were obese in 2015. Obesity among adults is more common than childhood obesity. However, the rate of obesity growth in many countries is higher in children compared to the growth rate of obesity among adults. From the 20 most populous countries, the highest level of adult obesity was observed in Egypt (35.3\%), while in the United States the highest level of obese children was observed (12.7\%) [6]. According to the results of the European Health Interview Survey (EHIS), in 2014 obese people in Poland accounted for $16.8 \%$ of the population aged 15 years and over [7]. This is an increasingly common problem in highly industrialized countries and also in developing ones [6]. Recent research shows that the worldwide rate of death related to high body mass index increased by $28.3 \%$ in the 25 years between 1990 and 2015 (from 41.9 to 53.7 deaths per 100,000 people). $70 \%$ of these deaths were caused by cardiovascular diseases [6].

Diet and lifestyle have a huge impact on human health. Consuming too many calories and limited physical activity can result in overweight or obesity. In addition to the calorific value of meals, the quality of the products used and the use of alcohol or cigarettes may matter. Proper nutrition means eating the right amount of nutrients with the right energy and nutritional value. 
That should maintain proper weight and a normally functioning body. Nutrition must therefore be adapted to the age of the person, sex, physiology, and the type of work performed.

It is important to identify the risk factors and early symptoms of cardiovascular diseases (CVD) at the earliest stage. The presence of certain pathologies is conducive to people leading a worse lifestyle than healthy people lead. Patients treated for cardiovascular events are less physically active, have worse dietary habits, and are more likely than healthy individuals to have addictions [8].

Adequate prophylaxis and treatment are also necessary in young people. Young people should be aware of the risk factors affecting health, and quality and length of life in the future. Physicians should be aware of common health risks in young patients. Young people with overweight and metabolic disorders should be referred to a dietitian. Family physicians should also remember lipid profile control and blood pressure measurement in this group of patients.

\section{Objectives}

The aim of the study was to evaluate the lifestyle of adult high school students (18-20 years old) from Lodz and to examine the relationship between the lifestyle and health of the respondents.

\section{Material and methods}

The study group consisted of 106 high school students in Lodz (76 women $-71.7 \%$ and 30 men $-28.3 \%$ ).

Inclusion criteria were: 1) age 18-20 years old, 2) being an adult high school student from one of three selected schools in Lodz, 3) patient's consent to participate in the study. Exclusion criteria were: 1 ) age below 18 years, 2) lack of consent to participate in the study (obligatory part - the questionnaire).

The study included: a questionnaire concerning lifestyle (physical activity, nutrition, alcohol, cigarettes), selected diseases (hypertension, diabetes mellitus type 2, dyslipidemia, overweight, obesity, hyperthyroidism and hypothyroidism), medication and anthropometric measurements. Body mass index $-\mathrm{BMI}\left(\mathrm{BMI}=\right.$ body mass $[\mathrm{kg}] /$ body height $\left.^{2}[\mathrm{~m}]\right)$ and waist-hip ratio - WHR $($ WHR $=$ waist circumference $[\mathrm{cm}] /$ hip circumference $[\mathrm{cm}])$ were calculated. Blood pressure (BP) was measured with the use of the Korotkov technique, 2 measurements in each participant, mean was calculated. Measurements were made in the sitting position after 5 minutes of rest.

In 35 volunteers out of the respondents, total cholesterol ( $\mathrm{CHOL}$ ), $\mathrm{HDL}$, triglyceridies (TG) and glycemia were marked. The level of $L D L$ cholesterol was calculated with the Friedewald formula (LDL cholesterol $=\mathrm{CHOL}-(\mathrm{TG} / 5+\mathrm{HDL})[9]$.

All 106 patients agreed to participate in the questionnaire and anthropometric measurements. 35 of them consented to a blood test.

The collected data were statistically analyzed using the STATISTICA 10.0 package. Conformity of distribution of quantitative variables with normal distribution was tested using the Shapiro-Wilk $\mathrm{W}$ test. The assumption of homogeneity of variance was checked using Levene's test. For analysis of the interdependencies of variables Student's $t$-test, ANOVA, the Mann-Whitney $U$ test, Analysis of Variance (ANOVA), the Kruskal-Wallis test and Spearman correlation were utilized. $P$-value $\leq 0.05$ was assumed as significant in all conducted tests. Table 1 (in the Results section) contains the $p$-value for the normal distribution test (Shapiro-Wilk test). If $p$-value $>0.05$, the variable had a normal distribution; if $p$-value $\leq 0.05$ - the distribution was not consistent with the normal distribution.

The study was approved by the Ethical Committee of the Medical University of Lodz.

\section{Results}

The study group consisted of 76 women (71.7\%) and 30 men (28.3\%). BMI $\geq 25.0 \mathrm{~kg} / \mathrm{m}^{2}$ was reported in $17.2 \%$ of the subjects, abnormal waist circumference (according to the International Diabetes Federation (IDF) 2006 and the Polish Forum for Prevention (PFP) consensus 2009 - women $\geq 80 \mathrm{~cm}$, men $\geq 94$ $\mathrm{cm}-7.5 \%$ and abnormal WHR (women $\geq 0.85$, men $\geq 0.9$ ) - in $0.9 \%$ of the subjects $[10,11]$. Abnormal systolic and/or diastolic BP values ( $\geq 130 / 85 \mathrm{~mm} \mathrm{Hg}$ ) were found in $3.8 \%$ of the subjects [11].

Out of the 35 participants who agreed to take part in the laboratory tests, elevated $\mathrm{CHOL}$ serum concentration was found in $3.8 \%$ of subjects, and abnormal LDL in $1.9 \%$. All participants had normal TG and HDL plasma cholesterol. Glycemia above the reference values was reported in $0.9 \%$ of the subjects. The descriptive characteristics of the examined group are summarized in Table 1.

\begin{tabular}{|c|c|c|c|c|c|c|c|}
\hline & $n$ & Average & Median & Min & Max & SD* & $p^{* *}$ \\
\hline Age (years) & 106 & 18.5 & 18.0 & 18.0 & 20.0 & 0.6 & $<0.001$ \\
\hline Weight (kg) & 106 & 63.2 & 60.3 & 30.0 & 110.6 & 14.0 & $<0.001$ \\
\hline Growth (m) & 106 & 1.7 & 1.7 & 1.5 & 1.9 & 0.1 & 0.3720 \\
\hline Waist circumference $(\mathrm{cm})$ & 106 & 72.6 & 70.5 & 50.0 & 100.0 & 9.7 & $<0.001$ \\
\hline Hip circumference $(\mathrm{cm})$ & 106 & 97.7 & 96.0 & 70.0 & 125.0 & 8.6 & 0.0268 \\
\hline $\mathrm{BMI}\left(\mathrm{kg} / \mathrm{m}^{2}\right)$ & 106 & 21.6 & 21.2 & 13.0 & 33.9 & 3.5 & 0.0073 \\
\hline WHR & 106 & 0.7 & 0.7 & 0.6 & 0.9 & 0.1 & 0.0010 \\
\hline Systolic BP (mm Hg) & 106 & 111.9 & 110.0 & 90.0 & 160.0 & 13.2 & 0.0040 \\
\hline Diastolic BP (mm Hg) & 106 & 66.9 & 65.0 & 50.0 & 90.0 & 8.1 & $<0.001$ \\
\hline $\mathrm{CHOL}(\mathrm{mg} / \mathrm{dl})$ & 35 & 161.3 & 161.0 & 122.0 & 220.0 & 22.5 & 0.4901 \\
\hline TG (mg/dl) & 35 & 77.8 & 70.0 & 39.0 & 144.0 & 27.6 & 0.0035 \\
\hline $\mathrm{HDL}(\mathrm{mg} / \mathrm{dl})$ & 35 & 62.5 & 63.0 & 45.0 & 80.0 & 9.3 & 0.6700 \\
\hline HDL\% & 35 & 39.5 & 39.0 & 25.0 & 58.0 & 7.4 & 0.2527 \\
\hline LDL (mg/dl) & 35 & 83.6 & 84.0 & 45.0 & 150.0 & 22.1 & 0.4156 \\
\hline Glycemia (mg/dl) & 35 & 85.1 & 85.0 & 74.0 & 99.0 & 6.4 & 0.5491 \\
\hline
\end{tabular}

*SD - standard deviation, **Shapiro-Willk test, BMI - body mass index, WHR - waist-hip ratio, BP - blood pressure, CHOL - total cholesterol, TG - triglycerides, HDL - HDL cholesterol, LDL - LDL cholesterol. 


\begin{tabular}{|c|c|c|c|c|c|}
\hline & CHOL & TG & HDL & LDL & Glycemia \\
\hline $\begin{array}{l}\text { Sex } \\
(\mathrm{W} \text { vs } \mathrm{M})\end{array}$ & $0.6318 *$ & $0.2420^{\#}$ & 0.0791* & $0.3403^{*}$ & $0.2411^{*}$ \\
\hline $\begin{array}{l}\text { Participation in PE classes } \\
\text { (yes vs no) }\end{array}$ & $0.3242 *$ & $0.6206^{\#}$ & $0.5400 *$ & $0.6107^{*}$ & $0.5433^{*}$ \\
\hline $\begin{array}{l}\text { Physical activity apart from PE classes } \\
\text { (yes vs no) }\end{array}$ & $0.2796^{*}$ & $0.9340^{\#}$ & $0.1924 *$ & $0.0944 *$ & $0.2900 *$ \\
\hline $\begin{array}{l}\text { Number of meals per day } \\
(<2 \text { vs } 2-3 \text { vs }>3)\end{array}$ & $0.6662 * *$ & $0.1548^{\# \#}$ & $0.0994 * *$ & $0.3406 * *$ & $0.5975^{* *}$ \\
\hline $\begin{array}{l}\text { Frequency of sweets consumption per week } \\
(1-2 \text { vs } 3-5 \text { vs } 7)\end{array}$ & $0.7990 * *$ & $0.1981^{\# \#}$ & $0.7579 * *$ & $0.8927^{* *}$ & $0.4240 * *$ \\
\hline $\begin{array}{l}\text { "Fast food" consumption } \\
\text { (yes vs no) }\end{array}$ & $0.0331 *$ & $0.6886 *$ & $0.8806^{*}$ & $0.0320 *$ & 0.7973* \\
\hline $\begin{array}{l}\text { Preferred type of food } \\
\text { (fruits/vegetables vs meat vs vegetarianism vs other) }\end{array}$ & $0.1470 * *$ & $0.9168 * *$ & $0.0978 * *$ & $0.5285^{* *}$ & $0.8957^{* *}$ \\
\hline $\begin{array}{l}\text { Relationship between food and stress } \\
\text { (yes vs no vs sometimes) }\end{array}$ & $0.7787^{* *}$ & $0.9710^{* *}$ & $0.2670 * *$ & $0.4240 * *$ & $0.9322^{\# \#}$ \\
\hline $\begin{array}{l}\text { Energy drinks intake } \\
\text { (yes vs no) }\end{array}$ & $0.3041^{*}$ & $0.8539^{\#}$ & $0.0005^{*}$ & 0.9519* & $0.8887^{*}$ \\
\hline $\begin{array}{l}\text { Cigarette smoking } \\
\text { (yes vs no) }\end{array}$ & $0.2231^{*}$ & $0.4391^{\#}$ & $0.4802^{*}$ & $0.2716^{*}$ & 0.3219* \\
\hline $\begin{array}{l}\text { Alcohol consumption } \\
\text { (yes vs no) }\end{array}$ & $0.7555^{*}$ & $0.7414^{\#}$ & $0.9508^{*}$ & $0.5655^{*}$ & 0.5649* \\
\hline $\begin{array}{l}\text { Medication } \\
\quad \text { (yes vs no) }\end{array}$ & $0.6585^{*}$ & $0.9858^{\#}$ & $0.4753 *$ & 0.9241* & $0.3195^{*}$ \\
\hline
\end{tabular}

W - woman, M - man, PE - physical education, *t-Student's test, **ANOVA, ${ }^{*} \mathrm{U}$ Mann-Whitney test, ${ }^{\# \# K r u s k a l l-W a l l i s ~ t e s t . ~}$

\section{Lifestyle of respondents}

Physical activity

$68.9 \%$ of the respondents participated in physical education (PE) classes. $58.5 \%$ declared physical activity besides physical education classes; on average 5.5 hours per week.

Diet

$64.2 \%$ declared consuming more than 3 meals a day. Nearly $30 \%-2$ or 3 meals a day. $6.6 \%$ of the respondents declared consuming fewer than 2 meals a day.

Sweets were consumed by $91.5 \%$ of participants; $41.5 \%$ ate such products no more than 2 times a week. $25.5 \%$ consumed sweets 3-5 times a week. A similar percentage of respondents (24.5\%) declared everyday consumption of sweets.

$51.9 \%$ declared eating "fast food". The vast majority of them (46.2\%) consumed such food 1-2 times a week, $4.7 \%$ of those examined 3-5 times a week, and daily only $0.9 \%$ of the respondents.

Approximately $39 \%$ of the respondents declared vegetables and fruits as their preferred type of food. $34 \%$ of the respondents indicated meat, $8.5 \%$ declared vegetarianism or "fast food" consumption (5.7\%). Other types of diet $-13.2 \%$ in total.

\section{Stress}

42.3\% of the respondents indicated a relationship between increased food consumption and stress - "sometimes" for $24.5 \%$ of the respondents, and "always" - for $19.8 \%$ of them.

\section{Protein supplements, energy drinks}

Protein supplements were used by $5.6 \%$ of respondents, 2-7 times a week. Nearly $24 \%$ consumed "energy" drinks (e.g. Burn, Red Bull, R20), in the amount of 0.1-2.0 litres per week.

\section{Alcohol and cigarettes}

Approximately $28 \%$ of the respondents reported smoking cigarettes, 1-70 per week. More than $50 \%$ consumed alcohol (therein $23.4 \%$ "occasional"). The rest drank 0.1 to 4.0 litres of alcohol per week.

\section{Medication}

Over $25 \%$ of the respondents reported medication. $85.2 \%$ took drugs every day, the rest 4 to 21 times a month. The most commonly used were contraceptives (43.2\%), antiallergic drugs $(15.4 \%)$, analgesics $(15.4 \%)$, endocrine treatment $(8.3 \%)$ and antidepressants $(7.6 \%)$

\section{The relationship between the values}

\section{of laboratory parameters and selected features of respondents}

The relationship between the values of laboratory parameters and selected features of the examined subjects was examined. The test probability values $p$ for the tested dependencies are summarized in Table 2 .

There was a statistically significant relationship between $\mathrm{CHOL}$ and serum LDL concentration and "fast food" consumption. Mean CHOL and LDL levels were higher in the group of students who declared "fast food" consumption than those who did not eat such food.

A statistically significant negative relationship was found between serum HDL cholesterol and energy drinks intake. Mean HDL level was higher in the case of people who didn't drink this type of beverage than those who drank energy drinks.

\section{Discussion}

According to the concept of the "health fields" identified by Lalonde, lifestyle influences more than $50 \%$ of an individual's health [12]. Abnormal nutrition and lack of physical activity are well known causes of overweight and obesity. Excessive body weight contributes to the development of dyslipidemia, hypertension or carbohydrate disorders. Each of these pathologies increase cardiovascular risk, as well as the risk of death.

In the study group, $68.9 \%$ of students participated in PE classes and nearly $60 \%$ declared physical activity in their lei- 
sure-time. In the study by Wojtyła-Buciora and Marcinkowski $89 \%$ of the 999 high school students in Kalisz declared participation in PE classes, and only $22 \%$ were physically active after school classes [13]. The differences between our research and the study by Wojtyła-Buciora and Marcinkowski may result from the different environmental and social background of the young people and their related lifestyle, e.g. students from Kalisz county were often engaged in farm work in their leisure-time.

Dietary habits are among the most important lifestyle elements. A survey conducted in 2012 among 160 high school students in Ostrołęka showed that $69 \%$ of them consumed more than 3 meals a day, and $31 \%-2$ or 3 meals [14]. These results are similar to the results obtained in our study (64\% consumed more than 3 meals, $29 \%$ ate $2-3$ meals, and about $7 \%-1$ meal). The study also revealed a high percentage of sweets and "fast food" consumption by high school students. $92 \%$ of the students from Ostrołęka declared sweets consumption, which corresponds to the results obtained in our study. Students from Ostrołęka consumed more "fast food", in comparison to the high school students in Lodz ( $77 \%$ vs $52 \%$ ). This may be due to societal differences (in bigger cities it seems more "fashionable" to be active, and presumably the place of living may affect how leisure-time is spent, physical activity or even diet). The comparable results confirm that sweets and "fast food" are constant ingredients of almost all young adults' diet. This may raise justified concerns about the dietary habits of this part of the population and the expected health consequences in future. It is interesting that $92 \%$ of school students (13-16 years old) from Warsaw declared regular sweets consumption (92\% of 101 students) [15]. Therefore, it seems necessary to improve the dietary habits not only of young adults, but also middle school students and probably primary school pupils.

Alcohol is commonly used among the examined group. We observed an alarming fact - that $50.9 \%$ of the respondents admit drinking alcohol. Although this is a much lower percentage than that obtained in a study conducted by the state agency responsible for solving alcohol problems (PARPA) in 2015 (96\% pupils from the second class drank alcohol), the number of alcohol-users in our study is high [16]. Similar results were obtained by Piotrowska et al. in a study from 2009 [17]. In a group of 409 Wroclaw girls - aged 16-18, 89\% declared drinking alcohol. In both studies the most common type of alcohol was beer, which was also confirmed in our study. Similar results show that the type of school does not influence the alcohol consumption (in Piotrowska et al.'s study $52.6 \%$ of the respondents attended a vocational secondary school, and the rest attended a general secondary school). An alarming fact is that even younger people declared alcohol consumption. The average age in which middle high school students from Szczecin reached for alcohol was 13 years. The average age at which they first got drunk was14 years [18].

Hypertension, dyslipidemia and hyperglycemia should be considered the first pathologies resulting from excessive body mass or incorrect lifestyle. In our study hypertension seems

Source of funding: This work was funded by the authors' resources. Conflict of interest: The authors declare no conflict of interests.

\section{References}

1. Must A, Spadano J, Coakley EH, et al. The disease burden associated with overweight and obesity. JAMA 1999; 282(16): 1523-1529.

2. Pi-Sunyer FX. The obesity epidemic: pathophysiology and consequences of obesity. Obes Res 2002; 10 (2): 97-104.

3. Szcześniak GR, Zdybel W, Kozak-Nurczyk P, et al. An evaluation of the prevalence of autoimmunological diseases in patients with diabetes and obesity hospitalized in the Department of Diabetology, Rural Medicine Institute in Lublin. Fam Med Prim Care Rev 2016; 18(3): 345-347.

4. Mazon JN, de Mello AH, Ferreira GK, et al. The impact of obesity on neurodegenerative diseases. Life Sci 2017; 182: 22-28.

5. Banaś IM, Lewek PK, Kardas P. In which group of children and adolescents should a family doctor look for metabolic syndrome? Fam Med Prim Care Rev 2016; 18(3): 217-220.

6. GBD 2015 Obesity Collaborators. Health effects of overweight and obesity in 195 countries over 25 years. 2017 [cited 23.06.2017]. Available from URL: http://www.nejm.org/doi/full/10.1056/NEJMoa1614362\#t=article.

7. Stan zdrowia ludności Polski w 2014 r. Warszawa: Główny Urząd Statystyczny; 2016 (in Polish). to be the most significant pathology in young adults. Elevated systolic and/or diastolic BP were found in $3.8 \%$ of the examined students. This is an alarming result, especially when compared results of the research on students of Lodz universities respondents [19]. However, Lodz university students, compared more often $(16.19 \%$ vs $7.5 \%)$ as well as improper WHR $(10.68 \%$ $0.9 \%$ [19]. This problem certainly requires further analysis. time, so perhaps nowadays there is a different approach to physical activity and diet. Additionally, high school students have mandatory PE classes at school. In the same research, BMI $\geq 25 \mathrm{~kg} / \mathrm{m}^{2}$ was observed in . Sulburska et al. also found similar results - in almost $23 \%$ of the 18 -year-olds from Wielkopolska, BMI values were $\geq 25 \mathrm{~kg} / \mathrm{m}^{2}[20]$.

\section{Limitations of the study}

Our study had some limitations. The surveyed population was relatively small but exceeded 100 people and appears to the requirements of statistical analysis. The main aim of dies in the field of glycemia and lipids was only an additional element of the work. There were 35 (out of 106 participants, 33\%) volunteers here, but some conclusions could be drawn. In the future, it would be worthwhile to conduct such a study on a larger group.

\section{Conclusions} meals every day Sweets and "fast food" are common diet components of high school students. A significant percentage of people drink alcohol and smoke cigarettes. are the most common problems among young people.

The physical activity of the examined group seems satisfactory. Most of the high school students are physically active in classes, and over half of them spend their the role of proper diet and physical activity in everyday life. Also, knowledge about the influence of smoking, alcohol intake stress on health should be promoted in primary care. It is physicians who take care of young adults should pay particular attention to the health problems that may result from an incorrect lifestyle. to the high school students, had improper waist circumference 
8. Muszyński J, Żółtańska J, Michalczak W, et al. Analiza stylu życia dorosłych mieszkańców Dolnego Śląska w aspekcie zapobiegania chorobom sercowo-naczyniowym. Fam Med Prim Care Rev 2016; 18(1): 33-38 (in Polish).

9. Kapoor R, Chakraborty M, Singh N. A leap above Friedewald Formula for calculation of lowdensity lipoproteincholesterol. J Lab Physicians 2015; 7: 11-16.

10. Alberti KG, Zimmet P, Shaw J. Metabolic syndrome - a new world-wide definition. A Consensus Statement from the International Diabetes Federation. Diabet Med 2006; 23: 475.

11. Polskie Forum Profilaktyki Chorób Układu Krążenia: Wytyczne PFP dotyczące zespołu metabolicznego. 2009 [cited 03.06.2017]. Available from URL: http://www.pfp.edu.pl/wytyczne/metaboliczny.html (in Polish).

12. Lalonde M. A new perspective on the health of Canadians: a working document. Ottawa: Government of Canada; 1974: 31-34.

13. Wojtyła-Buciora P, Marcinkowski JT. Aktywność fizyczna w opinii młodzieży licealnej i ich rodziców. Probl Hig Epidemiol 2010; 91(4): 644-649 (in Polish).

14. Łupacz E, Urban M. Nawyki żywieniowe młodzieży licealnej w wybranych szkołach w Ostrołęce. Łomża: Wydawnictwo Wyższej Szkoły Agrobiznesu w Łomży; 2013: 91-101 (in Polish).

15. Nitsch-Osuch A, Kędzierska M, Topczewska-Cabanek A, et al. Nawyki żywieniowe młodzieży w wieku gimnazjalnym - co nastolatki jedzą w szkole? Fam Med Prim Care Rev 2009; 11(3): 433-436 (in Polish).

16. Sierosławski J. Używanie alkoholu i narkotyków przez młodzież szkolnq. Raport z ogólnopolskich badań ankietowych zrealizowanych w 2015 r. Warszawa: Krajowe Biuro ds. Przeciwdziałania Narkomanii, Państwowa Agencja Rozwiązywania Problemów Alkoholowych; 2015: 19-36 (in Polish).

17. Piotrowska E, Żechałko-Czajkowska A, Biernat J, et al. Ocena wybranych cech stylu życia kształtujących stan zdrowia 16-18-letnich dziewcząt. Cz. I. Stosowanie różnych diet, aktywność fizyczna, palenie papierosów i picie alkoholu. Rocz Panstw Zakł Hig 2009; 60(1): 51-57 (in Polish).

18. Brzeźniak H, Mroczek B, Kotwas A, et al. Analiza wybranych zachowań zdrowotnych oraz samooceny masy ciała szczecińskich gimnazjalistów. Fam Med Prim Care Rev 2015; 17(2): 82-85 (in Polish).

19. Koziarska-Rościszewska M, Panasiuk M, Cypryk K. Prevalence of metabolic syndrome and its' components in the young adult - students of universities in Lodz, Poland. Pediatr Endocrinol Diabetes Metab 2010; 16(4): 277-283.

20. Suliburska J, Bogdański P, Pupek-Musialik D, et al. Analysis of life style of young adults in the rural and urban areas. Ann Agric Environ Med 2012; 19(1): 135-139.

Tables: 2

Figures: 0

References: 20

Received: 30.04 .2017

Revised: 17.06.2017

Accepted: 18.06 .2017

Address for correspondence:

Małgorzata Koziarska-Rościszewska, MD, PhD

Klinika Nefrologii, Nadciśnienia Tętniczego i Medycyny Rodzinnej UM

ul. Żeromskiego 113

90-549 Łódź

Polska

Tel.: +48 42 63-93-750

E-mail: malgorzata.koziarska-rosciszewska@umed.lodz.pl 